\title{
IMPROVING THE HEALTH STATUS OF WOMEN THROUGH PUBERTY RITES FOR GIRLS
}

\section{Thelmah X Maluleke}

D Litt et Phil

Department of Public Health and Centre for Youth Studies, University of Venda

Correspondence:Tmaluleke@univen.ac.za

Keywords: puberty rites; youth; sexuality education; HIV/AIDS; women

\begin{abstract}
The aim of this article is to present a sexuality education programme, which can be used in puberty rites for girls (vukhomba) to improve the health status of women in the community. The programme was developed from the inputs made by initiated girls and women participating in the puberty rites in the Limpopo Province. The purpose of the programme is to share information that will enable girls and women to have a responsible, satisfying and safe sex life and to prevent teenage pregnancy, STDs, HIV and AIDS. The need for this programme was identified during a study entitled "Puberty rites for girls in the Northern Region of the Northern Province of South Africa: Implications for women's health and health promotion." The purpose of this study was to explore and describe the events and activities of "vukhomba", to describe the content of the sexuality education given to girls during the rites and to explore the possibility of utilising vukhomba for the improvement of the health status of women. The study was designed as a qualitative, exploratory, descriptive and contextual research project. The ethnographic strategy was used to gain access to the "vukhomba" to view and describe the rites from an emic perspective.
\end{abstract}

\section{OPSOMMING}

Die oogmerk van hierdie artikel is om 'n seksualiteitsopvoedingsprogram voor te lê wat tydens die puberteitsrites vir meisies (vukhomba) gebruik kan word om die gesondheidstatus van vroue in die gemeenskap te verbeter. Die program is ontwikkel na aanleiding van die insette deur geïnisieerde meisies en vroue wat aan die puberteitsrites in die Limpopo Provinsie deelgeneem het. Die doel van die program is om inligting te verskaf wat meisies en vroue in staat sal stel om 'n verantwoordelike, bevredigende en veilige sekslewe te beoefen, en om tienerswangerskappe, seksoordraagbare siektes, HIV en VIGS te voorkom. Die noodsaaklikheid van so 'n program is geïdentifiseer tydens 'n studie getiteld "Puberteitsrites vir meisies in die Noordelike Streek van die Noordelike Provinsie van Suid-Afrika: Implikasies vir vrouegesondheid en die bevordering van gesondheid." Die doel van hierdie studie was om die gebeure en aktiwiteite van "vukhomba" te ondersoek en beskryf; om die inhoud van die seksualiteitsopvoeding te beskryf wat tydens die rites aan meisies gegee word; en om die moontlikheid te ondersoek dat die "vukhomba" gebruik kan word vir die verbetering van die gesondheidstatus van vroue. Die studie is ontwerp as 'n kwalitatiewe, ondersoekende, beskrywende en kontekstuele navorsingsprojek. Die etnografiese strategie is gebruik om toegang tot die "vukhomba" te verkry, om sodoende die rites vanuit die perspektief van 'n deelnemer waar te neem en te beskryf. 


\section{INTRODUCTION STATEMENT}

The Limpopo Province is one of the poorest provinces in South Africa, with a population of 4.9 million. It is mainly rural (89\%), with women in the majority (54\%) (Statistics South Africa, 2000:8-9). It has a young population, with almost 60 percent of the population below 20 years of age (Central Statistics Services, $1995: 12,47)$. Women in this area are mainly of a low status, illiterate and poor. They constitute, for example, 57 percent of the illiterate group (Central Statistics Services, 1995:52). Since the literacy and socioeconomic status of a woman plays a major role in reproductive health, in a province where more than 50 percent of the illiterate are women, it means that a large number of women have no access to information on reproductive health. Furthermore, social and cultural barriers prevent most of them from making decisions for themselves and their families. RaliphadaMulaudzi (1997:88) suggests that the norms of the society, customary marriages, and cultural expectations as social and cultural barriers, prevent women in rural areas from accessing reproductive health services.

Since the introduction of free health care at the primary health care level in South Africa, access to health care services for the inhabitants of the Limpopo Province has improved. In some rural areas, however, access to services is still a problem. People still walk more than five kilometres or use public transport to get to a primary health care centre. Access is more difficult for women who depend on other people to finance them or give them permission to visit a health care facility (Raliphada-Mulaudzi, 1997:88).

Another problem is that some health care facilities are overcrowded, and people wait for a long time before the health care providers see them. A study conducted by Hirschowitz and Orkin (1995:67) in South Africa, suggests that half of the African sample in their study waited for a minimum of two hours before a health worker saw them. In such a situation, health care providers often have no time for health promotion and for providing health education to the community.

The available health care facilities are not sensitive to the needs of teenagers. They do not give them the privacy they need and are not sympathetic and userfriendly. This makes it difficult for teenagers to seek professional assistance and advice when they need them, hence the lack of information, myths surrounding sexuality and non-usage of contraceptives. Troskie and Raliphada-Mulaudzi (1999:40) state that patients visiting reproductive health services entered screening rooms with other patients. In a study conducted by Raliphada-Mulaudzi (1997:88), adolescents indicated that providers of health services did not respect them and that they were treated like children. They would also prefer to have separate clinics for teenagers. Unfortunately there is at present only one youth clinic in the Northern Region, run by Planned Parenthood of South Africa (PPASA) in collaboration with the Department of Health and Welfare of the Limpopo Province. This clinic is only accessible to the youth that live in the nearby villages. Because of the inaccessibility of health education and health care services, women's health is in jeopardy. Should teenage girls be given the appropriate information through health education, these problems could be addressed and the health status of women could be improved. It needs to be taken into consideration that the health care services cannot manage to disseminate all health information on their own; other community resources must be looked at and utilised to help solve these problems.

At the Beijing Conference of 1995, women outlined their plan of action to address the plight of women across the whole world. They identified critical areas that affect the status and health of women, and also suggested some actions that their governments needed to work on. The plan is used as a guide to improve women's status and to reform governments and government policies (Report on the South African Government's Commitments arising from the Fourth World Conference, Beijing 1995:4-27).

The South African government has worked hard to develop policies that address most of the issues outlined at the Beijing conference. However, there are constraints on the implementation of some of the policies. The constraints range from understanding the policies to lack of commitment on the part of the service provider. Lack of knowledge about the available services and policies leads to lack of demand for the services. Women are not aware of the services and 
policies available to them. The suggested programme could be one of the methods that can be used to raise awareness about available services and facilities in the community.

This article discusses a programme that aims at improving the health status of women through puberty rites. The programme is based on the inputs of initiated women and girls who participated in the puberty rites for girls. It is an intervention programme for dealing with needs and problems identified in two other articles entitled "The views of women in the Limpopo province of South Africa concerning girls' puberty rites" (Maluleke \& Troskie, 2003) and "Sexuality education, gender and health issues related to puberty rites for girls" (Maluleke, 2003). The findings of these studies discussed in the abovementioned articles suggest that:

- The puberty rites do not challenge gender inequalities in the society. They reinforce women's roles and stereotypes. Women temporarily acquire recognition and status in the community, but once the rites are over, they unfortunately go back to the low status prescribed by society.

- Virginity is encouraged for male satisfaction, therefore making it a gender issue, because males are not encouraged to be virgins.

- Sexuality education in the puberty rites is limited to personal hygiene, maintaining virginity, selfcontrol and social morals.

- Sexuality education in the rites covers the most important aspects in the prevention of HIV, which is abstinence, but does not teach initiates about HIV/AIDS.

- Sexuality education in the rites is done in a nonthreatening environment, which allows the use of the correct names for the reproductive organs.

- The teachings in the rites are done through singing, poems, demonstrations and managa (figurines) that are shown to the initiate. These are effective learning methods used in the promotion of health.

- Sexuality education in puberty rites encourages self-control, which is one of the basic elements of sexual health.

\section{PURPOSE OF THE ARTICLE}

The purpose of this article is to discuss:
- the intervention programme that can be employed to deal with gender and health issues in the puberty rites for girls; and

- the ways in which the vukhomba can be used to improve the health status of women.

\section{RESEARCH DESIGN AND METHODS}

After reviewing the findings of the two articles mentioned above, an intervention programme to improve the health status of women was developed. During September 2000 the draft intervention programme was presented to the vukhomba elders, initiated women and initiated girls in the form of a health education talk to give them an opportunity to comment on the programme. Since the objective of the health talk was to assist the vukhomba participants in making an informed decision on what should be included in the intervention programme, the presentation was not formally evaluated. However, the participants' ability to choose the topics they wanted in the proposed programme serves as an indication that they have understood the content of the programme. Table 1 indicates the topics presented and participants' responses or choices.

All the vukhomba participants approved eight of the eleven topics presented for inclusion in the intervention programme. Both vukhomba elders and initiated women disapproved the inclusion of the male reproductive organs and the topic on pregnancy. The vukhomba elders also disapproved the topic on contraceptives.

Although all participants showed a lot of interest in all aspects related to the pregnancy topic, vukhomba elders and initiated women disapproved it for two reasons. Firstly, in their view initiates are too young to learn about pregnancy. Secondly, it would be disrespectful to discuss this topic in the presence of young people. For example, a participant in one of the discussions said: "You know, I will still be in a position to get children when my first daughter goes to vukhomba. After getting this information, how will she look at me when I am pregnant? She will know what is going on inside me". Another participant indicated that she does not want young girls (initiated and uninitiated) to read her like a book. In her view the information on pregnancy is like exposing herself to the pub- 
Table 1: Topics presented to the vukhomba participants and their responses

\begin{tabular}{|c|c|c|c|}
\hline \multirow[t]{2}{*}{ Topics } & \multicolumn{3}{|l|}{ Responses } \\
\hline & $\begin{array}{l}\text { Vukhomba } \\
\text { elders }\end{array}$ & Initiated women & $\begin{array}{l}\text { Initiated } \\
\text { girls }\end{array}$ \\
\hline $\begin{array}{l}\text { Anatomy and physiology of the female } \\
\text { reproductive system }\end{array}$ & Approved & Approved & Approved \\
\hline $\begin{array}{l}\text { Anatomy and physiology of the male } \\
\text { reproductive system }\end{array}$ & Not approved & Not approved & Approved \\
\hline $\begin{array}{l}\text { The developmental stages of the } \\
\text { woman }\end{array}$ & Approved & Approved & Approved \\
\hline Menstruation & Approved & Approved & Approved \\
\hline Pregnancy & $\begin{array}{l}\text { Not approved, } \\
\text { but lot of interest }\end{array}$ & $\begin{array}{l}\text { Not approved, but } \\
\text { lot of interest }\end{array}$ & Approved \\
\hline Contraception & Not approved & Approved & Approved \\
\hline Personal hygiene & Approved & Approved & Approved \\
\hline Sexually Transmitted Diseases (STDs) & Approved & Approved & Approved \\
\hline HIV/AIDS & Approved & Approved & Approved \\
\hline Breast examination and ca breast & Approved & Approved & Approved \\
\hline Cancer of the cervix and pap-smear & Approved & Approved & Approved \\
\hline
\end{tabular}

lic for scrutiny. She seemed to be holding the view that information about pregnancy should be limited to female adults.

All the topics that were not approved by the vukhomba elders were left out of the final intervention programme. However, it is hoped that some of them could be handled if questions arise.

Although the intervention programme is based mainly on the topics suggested by the vukhomba elders, the work of The Allen Guttmacher Institute (2000:5) and those of Tinker, Finn and Epp (2000:27) were taken into consideration when the intervention was developed. The programme addresses the identified gender and health issues, the developmental stages of the woman, and conditions and diseases affecting women, such as sexually transmitted diseases, HIV and AIDS. The programme will be given to initiated women who oversee vukhomba and they will be guided on how to use it in the ceremony.

According to The Allan Guttmacher Institute (2000:5), sexuality educational programmes should aim at:
- encouraging teenagers to postpone intercourse;

- supporting the sexually experienced youth who wish to refrain from sexual activities;

- preparing the youth to adequately prevent teenage pregnancy and sexually transmitted diseases;

- improving access to information and youth health services;

- providing adequate education and information about sexual behaviour; and

- providing support for research into new contraceptive methods and youth health.

According to Tinker et al. (2000:27), essential intervention for women's health should address:

- prevention and management of unwanted pregnancy;

- $\quad$ services related to pregnancy;

- prevention and management of STDs and gynaecological cancers;

- promotion of positive health practices; and

- elimination of harmful practices.

Taking all this information into consideration, the gen- 
eral aims of the intervention programme were developed.

\section{THE INTERVENTION PROGRAMME}

\section{General aims of the intervention programme}

- To share information that will enable girls and women to develop a responsible, satisfying and safe sex life.

- To share information that will assist girls and women in forming attitudes, beliefs and values about sexuality development, for example, why girls menstruate, reproductive health, interpersonal relationships and body image (know your body).

- To prevent teenage pregnancy, STDs, HIV and AIDS.

\section{Learning methods}

The programme is based on popular or emancipatory education. It will be presented as a workshop and the inductive learning approach or LePSA method of teaching will be used. The inductive learning approach is a non-formal, inductive and non-directive method, sometimes called the psychosocial method. It is an adaptation of the method developed by the Brazilian adult educator, Paulo Freire. The psychosocial method of teaching is nicknamed LePSA (Learner-centred, Problem-posing, Self-discovery and Action-oriented). This method is generally used in South Africa for raising awareness and to challenge the inequalities in the South African society (University of Western Cape, 1992:32).

This popular educational approach was adopted in South Africa because, firstly, it is about collective learning and takes a political stand on the side of marginalised people. Using the method, the facilitator can create situations in which people with different cultural or educational backgrounds can make sense of the world together. This happens by sharing experiences, and once they have a new understanding, they can decide what actions they will take to challenge whatever is causing their problems. That is, it begins with people's experiences, moving to analysis of the experiences, then encouraging collective action on the problem, and reflection and evaluation of its own process (Boud, Cohen \& Waller, 1993:26-30).

In each session a starter will be used to begin a discussion. The starters will be role-play, a case study, poem, figurine or games. Each session will be problem-posing and the participants will try and solve the problem. At the end of each session each participant will evaluate the session and identify what has been learned or unlearned from it. This will assist in identifying gaps in each session, and issues, which might be making some of the participants uncomfortable. The information will assist the facilitator when making plans for the next session. All sessions will be presented in Xitsonga.

The content of the intervention programme includes the female body, the developmental stages, personal hygiene, STDs and HIV/AIDS, breast examination, cancers affecting women, gender and health and women's rights. Gender and women's rights will not be taught as a topic, but will be incorporated in all topics listed above.

The researcher will facilitate the initial programme. After the presentation of the first programme, the participants will meet with the researcher to evaluate the programme and make decisions on the way forward. The meeting will also discuss how the programme can be integrated into the proceedings of vukhomba. If the programme is found to be acceptable, facilitators for each village will be trained to run the programme. A facilitation guide will be developed and an information booklet in Xitsonga will be compiled to make it accessible to the whole community. Since vukhomba is also practised in other districts, the programme will be extended to those areas.

\section{WAYS IN WHICH THE VUKHOMBA CAN BE USED TO IMPROVE THE HEALTH STATUS OF WOMEN}

Since vukhomba brings initiated women and initiated girls together, it can act as a place of health promotion and health education for different age groups. The initiated girls can be used for peer group teaching not only in the initiation, but also in the community and at school. The initiated women should be trained to facilitate workshops for women. The initiated women will 
run workshops for initiated and uninitiated women in the community. Vukhomba can also be used for disseminating new health information, for example disease outbreaks and immunisation campaigns. The intervention programme should be an integral part of vukhomba.

\section{CONCLUSION}

Vukhomba, as a cultural event can be used for health promotion. It can be used to empower women and improve their health. There is a need for sexual health information to reach all girls in the country. The Limpopo Province Department of Health and Welfare, at all levels, should ensure that co-operation is established between vukhomba elders and the health services. The vukhomba elders should be allowed to participate in primary health care as stakeholders and form part of the health team. This will ensure that the cultural rites can be used to promote women's health.

Puberty rites should be used for teaching and for the prevention of disease, for example, HIV/AIDS, cancers and STDs. The programme should be in line with the programme given in the schools and therefore discussions should be held with the relevant department. Further research studies are recommended to study the impact of the programme in the puberty rites and community.

\section{REFERENCES}

BOUD, D; COHEN, R \& WALLER, D 1993: Using experience for learning. Buckingham: SRHE \& Open University Press.

CENTRAL STATISTICS SERVICES 1995: Report on provincial statistics: Northern Province. Pretoria: Central Statistics.

CRESWELL, JW 1994: Research design: qualitative and quantitative approaches. Thousand Oaks: SAGE.

HIRSCHOWITZ, R \& ORKIN, M 1995: A National household survey of health inequalities in South Africa. New York: Kaiser Foundation. MALULEKE, TX 2003: Sexuality education, gender and health issues related to puberty rites for girls. Health SA Gesondheid, 8(3).

MALULEKE, TX \& TROSKIE, R 2003: The views of women in the Limpopo Province of South Africa concerning girls' puberty rites. Health SA Gesondheid, 8(3).

RALIPHADA-MULAUDZI, FM 1997: Reproductive Health Rights of Women in Rural Communities. Unpublished MA Cur Dissertation, Pretoria: University of South Africa.
REPORT ON THE SOUTH AFRICAN GOVERNMENT'S COMMITMENTS ARISING OUT OF THE FOURTH WORLD WOMENS' CONFERENCE 1995: Beijing.

STATISTICS SOUTH AFRICA 2000: Stats in Brief. Pretoria: Stats $S A$ information.

THE ALAN GUTTMACHER INSTITUTE 2000: Trends towards abstinence-only sex-ed means many U.S. Teenagers are not getting vital messages about contraception. Available: New York News Release Website, http://www.agi-usa.org/pubs/ or_teen_preg_decline.html

TINKER, A; FINN, K \& EPP, J 2000: Improving women's health: Issues \& interventions. Human Development Network. World Bank. TROSKIE, R \& RALIPHADA-MULAUDZI, FM 1999: Reproductive health rights of women in rural communities. Health SA Gesondheid, 4(1):41-47.

UNIVERSITY OF WESTERN CAPE 1992: Report on the first training of facilitators' course in South Africa. University of Western Cape: Unpublished 